\title{
Water Purification Technology Implementation Design
}

\author{
Anggara Trisna Nugraha a,1, Rahman Arifuddin ${ }^{\mathrm{b}, 2}$ \\ a Politeknik Perkapalan Negeri Surabaya, Jl.Teknik Kimia, Surabaya 60111, Indonesia \\ b Universitas Merdeka Malang, J1.Terusan Raya Dieng No. 62-64, Malang 65146, Indonesia \\ ${ }^{1}$ anggaranugraha@ppns.ac.id *; ${ }^{2}$ rahman.arifuddin@unmer.ac.id; \\ * corresponding author
}

\begin{tabular}{|c|c|}
\hline & ABSTRACT \\
\hline $\begin{array}{l}\text { Keywords } \\
\text { Filtration } \\
\text { Water Purifier } \\
\text { pH } \\
\text { Water Level } \\
\text { Clarity }\end{array}$ & $\begin{array}{l}\text { Seeing the condition of water availability with good quality which is starting to decrease, } \\
\text { it is necessary to have water treatment before the water is suitable for use. Therefore, in } \\
\text { this research, a more effective digital measuring instrument is designed to measure water } \\
\text { quality in terms of pH and water clarity. The design of tools in the form of natural filtration } \\
\text { and pH measuring devices. This study used several water samples, namely rainwater and } \\
\text { well water from different locations. Based on the test results, the tool works effectively } \\
\text { with a pH value that has been in the standard range from the start }(6.5-9) \text { after } 4 \text { times of } \\
\text { filtration, which is between } 6.82-7.60 \text { so that the pH value of the water will be maintained } \\
\text { in a condition that is fit for use. . For acidic and alkaline pH categories, it requires repeated } \\
\text { processing to get the value according to the standard fit for use }\end{array}$ \\
\hline
\end{tabular}

\section{Introduction}

Water is a basic human need. In everyday life, water is always used for drinking, bathing, washing and other necessities. However, the availability of water still does not meet clean water standards[1]. There are several parameters that can be used to determine water quality, namely physical parameters, chemical parameters, and biological parameters[2][3].

To overcome this condition, it is necessary to have water treatment so that the water used meets the standards of clean water suitable for use[4][5]. Research on water treatment has been carried out by various methods, both in terms of filtration and sensors used. This research will design a more effective digital measuring instrument for measuring water parameters in terms of $\mathrm{pH}$, clarity, and the use of natural filtration and water level control as an automation system

\section{Method}

\subsection{Block Diagram}

The method of designing tools is by providing research support tools and materials in the form of hardware ( $\mathrm{pH}$ sensor, LDR, Electro Tester, LCD, Arduino uno, Natural Filtration Materials, HC-SR 04, and UV Filtration) and software (Eagle PCB and Arduino IDE). This research consisted of several stages, namely the design of the hardware, the connection between the hardware, the manufacture of the software, the synchronization between the hardware and the software, and the stages of testing and analysis of the results. The following is the design of the water purifier hardware design 


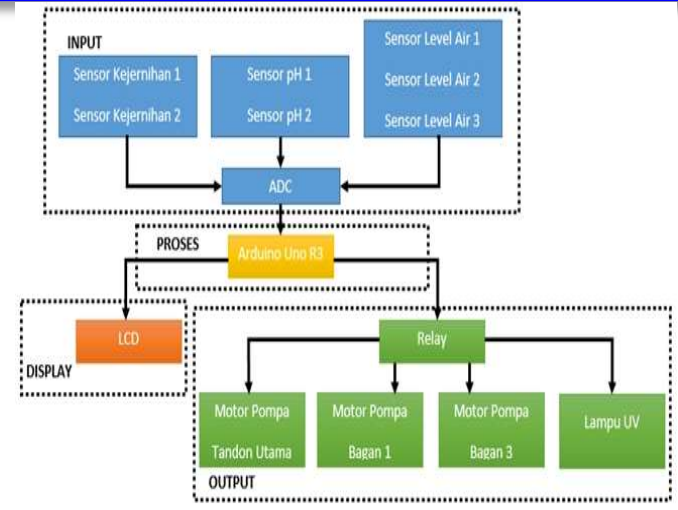

Fig 1. Block Diagram

\subsection{Flowchart System}

The flow of the water purifier testing process is the initialization of the $\mathrm{pH}$ sensor, the water level sensor, the clarity sensor, the electrolysis is on, pump A is on, pump B is off, pump C is off, and the UV lamp is on. Seen in Figure 2. Design of a water purifier Can be seen in Figure 3. consists of 4 charts, namely chart 1 as a place for input sensors and initial value taking, chart 2 as a place for filtration materials and a water level sensor. Chart 3 to place the final input sensor.

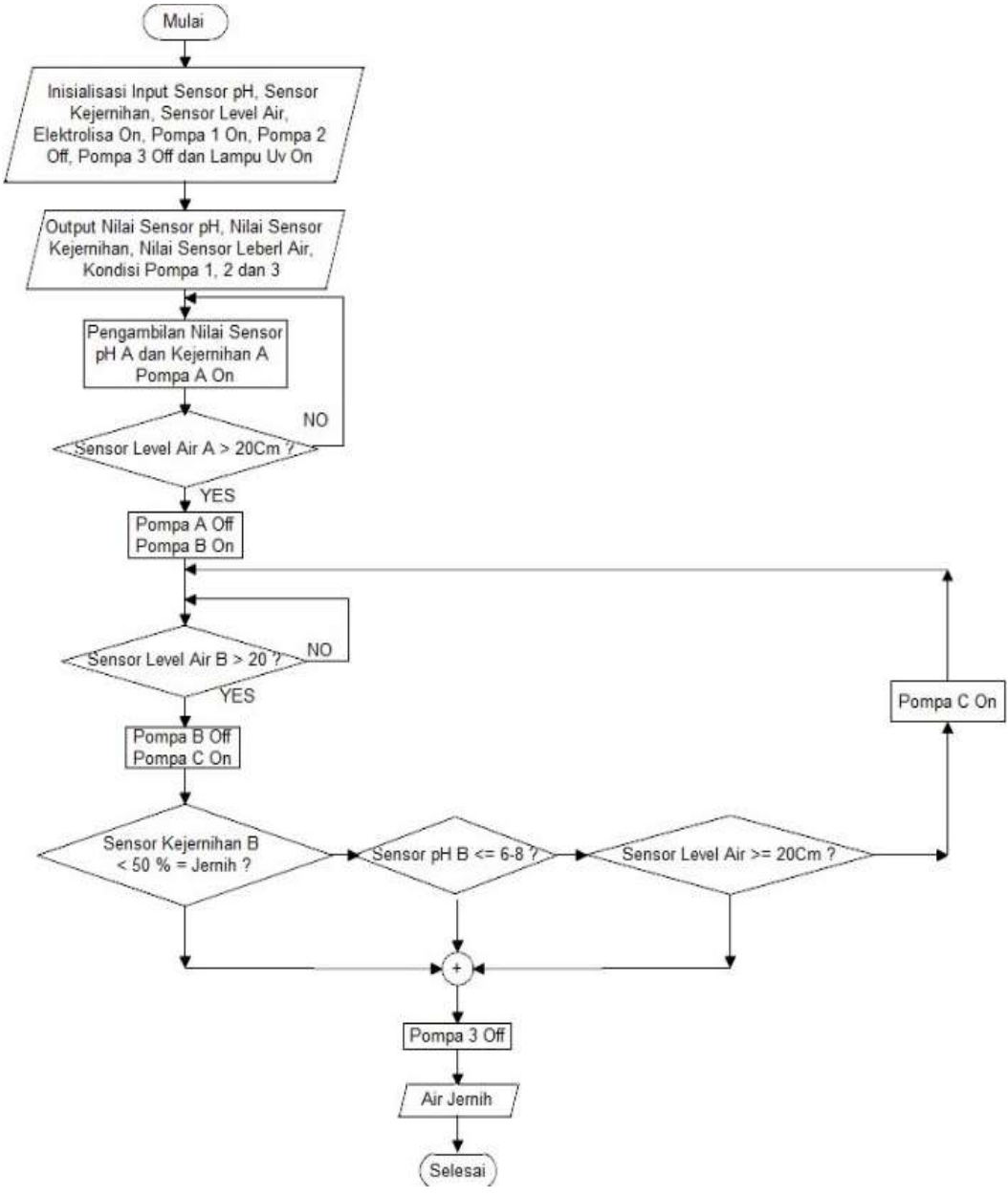

Fig 2. Flowchart

144 | P a g e 
The following is the design of the tool as a whole. In this study, a pH sensor, HC-SR 04 sensor and clarity sensor were also calibrated to obtain results that match the tools that have become the benchmark for calibration. Calibration is carried out on all sensors used[5].

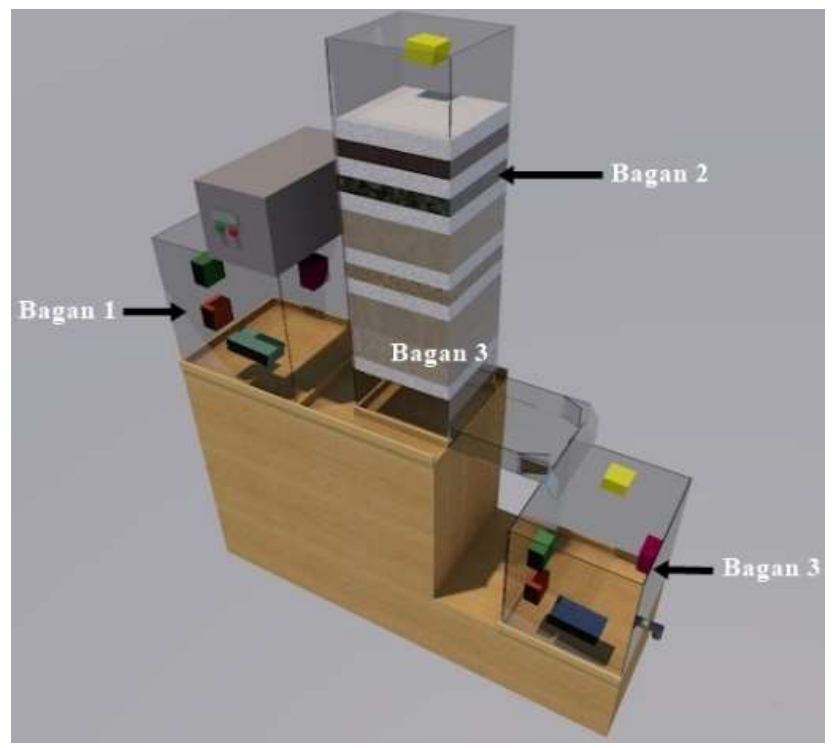

Fig 3. The overall tool design plan

\section{Results and Discussion}

Discussion of the test results include sensor testing, Arduino Uno R3 testing, relay testing, power supply testing, sensors and testing the work system as a whole

\subsection{Water Filtration Testing}

Based on the results of the water filtration test from the catfish pond in table 1. with 4 experiments it was found that the more it was done repeatedly, the results obtained from the filtration process would be the smaller the NTU value. At the beginning of the pool water a value of 194NTU was detected. When the filtration process has been carried out up to 4 times the water looks clear, so the value is 7NTU. From the results of this test it can be said that the value of the filtration test is effective with 4 trials. The smaller the NTU level, the cleaner the water it produces.

Table 1. Water Filtration Test Results

\begin{tabular}{ccc}
\hline No & Water Condition & ( NTU ) \\
\hline 1 & $\begin{array}{c}\text { Water from catfish } \\
\text { ponds }\end{array}$ & 194 \\
\hline 2 & Filtered 1 & 67 \\
\hline 3 & Filtered 2 & 45 \\
\hline 4 & Filtered 3 & 43 \\
\hline
\end{tabular}

\subsection{Testing the Water Level Sensor (Ultrasonic HC-SR04)}

Based on the test results in table 2 and table 3. sensors HC-SR 04 A, HC-SR 04 B and HC-SR 04 $\mathrm{C}$ with a predetermined distance prove that the sensor used is functioning properly and is close to the true value[6]. It can be seen from the error percentage value. 
Table 2. HC-SR 04 Sensor Test Results

\begin{tabular}{ccccc}
\hline No & Distance Measured On Ruler & HC-SR04 A & HC-SR04 B & $\begin{array}{c}\text { HC-SR04 } \\
\text { C }\end{array}$ \\
\hline 1 & 5 & 5,04 & 4,89 & 4,96 \\
\hline 2 & 6 & 6,09 & 6,16 & 6,23 \\
\hline 3 & 7 & 7,14 & 7,21 & 7,28 \\
\hline 4 & 8 & 8,05 & 8,12 & 8,19 \\
\hline
\end{tabular}

Table 3. Test Results Error\% Sensor HC-SR 04

\begin{tabular}{cccc}
\hline No & $\begin{array}{c}\text { Error \% HC-SR 04 } \\
\text { A }\end{array}$ & Error \% HC-SR 04 B & Error \% HC-SR 04 \\
\hline 1 & 0,80 & 2,20 & C \\
\hline 2 & 1,50 & 2,67 & 1,59 \\
\hline 3 & 2,00 & 3,00 & 3,83 \\
\hline 4 & 0,63 & 1,50 & 4,00 \\
\hline
\end{tabular}

\subsection{Testing of the degree of acidity $(\mathrm{pH})$ sensor}

\section{a. $\quad$ pH buffer testing 4}

Based on the test results using $\mathrm{pH} 4$ buffer, it can be seen in table 4 . The error percentage value is still large because the sensor is very sensitive to acid-containing materials. Likewise, the test material has decreased in quality because the test material has been contaminated with other $\mathrm{pH}$ when testing repeatedly. So that the results obtained when testing the $\mathrm{pH} 4$ buffer were less than optimal.

b. $\quad$ H buffer testing 8

The results of the percent error in table 4.The percent error results obtained show the value that has a small percent error. So that the $\mathrm{pH}$ value of the buffer and the $\mathrm{pH}$ of the measurement are also not much different or close to the same. The $\mathrm{pH}$ sensor in measuring alkaline alkaline $\mathrm{pH}$ shows the ideal value.

c. $\mathrm{pH}$ buffer testing 9

The results of the error in table 4. the percent obtained, show the value that has a small percent error. So that the $\mathrm{pH}$ value of the buffer and the $\mathrm{pH}$ of the measurement are not much different or close to the same. The $\mathrm{pH}$ sensor in measuring alkaline $\mathrm{pH}$ shows the ideal value.

Table 4. Test Results Using Buffer $\mathrm{pH} 4,8$ and 9

\begin{tabular}{ccccc}
\hline No & $\begin{array}{l}\text { Original } \\
\mathbf{p H}\end{array}$ & ADC & $\mathbf{p H}$ measurement & $\begin{array}{c}\text { Error } \\
\mathbf{\%}\end{array}$ \\
\hline 1 & 4 & 686 & 4,49 & 12,25 \\
\hline 2 & 4 & 676 & 4,80 & 20,00 \\
\hline 3 & 4 & 680 & 4,70 & 17,50 \\
\hline 4 & 8 & 604 & 8,24 & 3,00 \\
\hline 5 & 8 & 604 & 8,24 & 3,00 \\
\hline 6 & 8 & 588 & 8,55 & 6,88 \\
\hline 7 & 9 & 492 & 9,59 & 6,56 \\
\hline 8 & 9 & 447 & 9,43 & 4,78 \\
\hline 9 & 9 & 487 & 9,72 & 8,00 \\
\hline
\end{tabular}

\section{d. Clarity Sensor Testing}

The clarity sensor test was carried out with conditions in clean water, with $1 \mathrm{ml}$ ink, $2 \mathrm{ml}$ ink, and $3 \mathrm{ml}$ ink. In the table, $3 \mathrm{x}$ data collection in the form of $\mathrm{ADC}$ value is taken and the conversion result from $\mathrm{ADC}$ value to clarity value is taken. Based on the whole table, it can be seen that the more cloudy the water in the container, the greater the $\mathrm{ADC}$ value of the clarity sensor, and vice versa, the clearer the water in the container, the smaller the ADC value. 


\begin{tabular}{cccc}
\hline No & Ink & ADC & Clarity Value \\
\hline 1 & $2 \mathrm{ml}$ & 749 & 72.65 \\
\hline 2 & $2 \mathrm{ml}$ & 753 & 73.04 \\
\hline 3 & $2 \mathrm{ml}$ & 748 & 72.56 \\
\hline
\end{tabular}

\section{e. Testing the Implementation of Water Purifier Technology Design}

Figure 5. above is the result of the actual tool design. The design in the first chart is used to determine the condition of the water based on the condition of the acidity and clarity values, then proceed to the second chart which is used as filtration to maintain or change the $\mathrm{pH}$ value and clarity, and the third chart is used to determine the value of the filtration result. If the results of the filtration are not suitable, it will be repeated until you get the desired value.

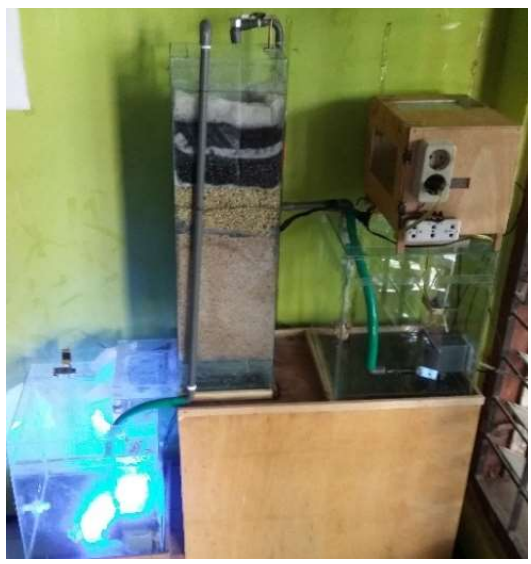

Fig 5. Water Purification Technology Design

After testing the tool as a whole, the results of the test results show that the $\mathrm{pH}$ value and the clarity of the water test samples from different conditions and different places are obtained. The results of the electronic combination are then implemented in the design of the tool so that the tool works well and can take the value of the clarity and initial $\mathrm{pH}$ parameters. as well as the $\mathrm{pH}$ value and final water clarity so that a comparison of the values can be carried out both before and after being filtered.

\section{f. Testing the Implementation of Water Purification Technology Design with test objects}

At this stage the test results are carried out using test objects which use the independent variable in the form of water conditions that are different from places and sources. The water sample only took water in the Jember Regency area. The water used is well water, rainwater and PDAM water.

In testing the $\mathrm{pH}$ levels in the test sample, 4 samples of test water were taken where water that had a high acid level to a high alkaline level and water that was already in neutral conditions from the start. The clean water quality requirements that water is fit for use are for the $\mathrm{pH}$ category in the range of 6.5-9. it can be seen in the well water in the Patrang sub-district where the water is acidic and the well water in the muktisari area where the water is wet. The water is filtered with the same treatment, which is 4 times the results obtained exactly in accordance with the range of acidity suitable for use. Meanwhile, water that has a neutral value from the start, such as on Jl. Java and PDAM, the water with the same treatment is filtered 4 times, the value of the water is maintained at neutral conditions.

In the test of the level of clarity where the water condition is suitable for use, it is below $25 \mathrm{NTU}$. With the same test object and the same treatment, namely water is tested and repeated 4 times. From table 7 it can be seen that from the beginning the water was clean and clear. When the water is filtered, the clarity is maintained. very sensitive to changes, especially in materials that contain acids and the clarity sensor is very sensitive to changes in light conditions from outside. The filtration conditions will be maximized and effective if it is carried out continuously, both in terms of the filtration material itself will be clean as well as the water produced. 
JEEMECS (Journal of Electrical Engineering, Mechatronic and Computer Science

ISSN 2614-4859

Vol. 3, No. 2, August 2020, pp. 143-148

doi https://doi.org/10.26905/jeemecs.v3i2.4583

Table 6. Test Conditions of $\mathrm{pH}$ Levels in Test Water Samples

\begin{tabular}{|c|c|c|c|c|c|c|}
\hline No & Water Sample District. Jember & $\begin{array}{c}\text { pH Water } \\
\text { Filter }\end{array}$ & $\begin{array}{c}\text { pH Water } \\
\text { Filter } 1\end{array}$ & $\begin{array}{c}\text { pH Water } \\
\text { Filter } 2\end{array}$ & $\begin{array}{c}\text { pH Water } \\
\text { Filter } \mathbf{3}\end{array}$ & $\begin{array}{c}\text { pH Water } \\
\text { Filter } 4\end{array}$ \\
\hline 1 & Air Cuka $160 \mathrm{ml}$ & 5,85 & 5,98 & 6,34 & 6,78 & 7,10 \\
\hline 2 & Air Cuka $460 \mathrm{ml}$ & 5,32 & 5,82 & 6,15 & 6,64 & 6,98 \\
\hline 3 & Air Cuka $760 \mathrm{ml}$ & 4,73 & 5,04 & 5,77 & 6,25 & 6,82 \\
\hline 4 & Air Cuka $900 \mathrm{ml}$ & 4,54 & 4,83 & 5,20 & 5,67 & 6,26 \\
\hline
\end{tabular}

Table 7. Test Condition Value of Clarity Levels in Test Water Samples

\begin{tabular}{|c|c|c|c|c|c|c|}
\hline No & Water Sample District. Jember & Initial Clarity & $\begin{array}{c}\text { Initial Clarity } \\
1\end{array}$ & $\begin{array}{c}\text { Initial Clarity } \\
2\end{array}$ & $\begin{array}{c}\text { Initial Clarity } \\
\mathbf{3}\end{array}$ & $\begin{array}{c}\text { Initial Clarity } \\
4\end{array}$ \\
\hline 1 & Air Sumur wil. Muktisari & 2,05 & 2,14 & 2,23 & 2,31 & 2,23 \\
\hline 2 & Air Sumur Wil. Jl. Kalimantan & 2,23 & 3,05 & 3,14 & 2,23 & 1,14 \\
\hline 3 & Air Sumur Wil. Jl. Jawa & 2,77 & 2,59 & 2,49 & 2,41 & 2,23 \\
\hline 4 & Air Sumur Wil. Patrang, Dr Soebandi & 4,14 & 3,23 & 2,23 & 2,14 & 1,77 \\
\hline
\end{tabular}

\section{Conclusion}

When testing $\mathrm{pH}$, the $\mathrm{pH}$ sensor used is very sensitive to changes, especially in materials that contain acids and the clarity sensor is very sensitive to changes in light conditions from outside. When testing water that is in extreme conditions, namely acidic (below 4.5) or wet (above 9), it requires a repeated filtration process to get the value according to the wearable standard

\section{References}

[1] L. Madhura, S. Kanchi, M. I. Sabela, S. Singh, and K. Bisetty, "Membrane technology for water purification," Environ. Chem. Lett., vol. 16, no. 2, pp. 343-365, 2018.

[2] J. Singh, V. Saharan, S. Kumar, P. Gulati, and R. K. Kapoor, "Laccase grafted membranes for advanced water filtration systems: a green approach to water purification technology," Crit. Rev. Biotechnol., vol. 38, no. 6, pp. 883-901, 2018.

[3] A. T. Nugraha, "DIRTY AIR FILTER SYSTEM USING BOXED EQUALIZER MQ-8 AND MQ-9 WHEELED ROBOT," JEEMECS (Journal Electr. Eng. Mechatron. Comput. Sci., vol. 1, no. 1, pp. 23-26, 2018.

[4] A. J. Jose, A. M. Jacob, K. C. Manjush, and J. Kappen, "Chitosan in water purification technology," Green Sustain. Adv. Mater. Appl., 2018.

[5] A. T. Nugraha, "Rancang Bangun Teknologi Pemurni Air," Universitas Jember, 2015.

[6] S. Sjogelid, Raspberry Pi for Secret Agents. 2013. 